\title{
Causes of Child Sex Tourism Systematic
}

\author{
Yahya Muhammed Bah, Pinky Saptandari
}

\begin{abstract}
The tourism industry beyond all reasonable doubts is not only one of the most rapidly growing industries in the globe but one of the largest employer generating billions of dollars annually. However, in spite of that, the industry according to nascent studies has some profound negative socio-economic, political, cultural and environmental impacts on communities. For instant, tourists engaging children in sex for which they are not ready for both physically, mentally and psychologically has negatively impacted them physically, psychological, mentally, emotionally, economically; and socially. Some have even died. Although the precise number of child sex tourism casualties and their circumstances is not scientifically well researched and documented, what is indisputable is they are in millions. This lack of scholarly documentation, beyond reasonable doubt has posed a great challenge to all concern authorities. Thus, this research was meant to address this gap. The fundamental rationale for the systematic literature review is to examine the present scale and degree of the causes of child sex tourism, share knowledge to spark and inspire processes that will usher rapid growth from all directions in the fight against the menace. A systematic review of the literatures using information collected from different sources was actuated. Google Search Engine was used to search these articles. During the search numeration combinations of words and phrases were used to ensure articles reflect the most recent knowledge and scholarly works. In essence, only peer-reviewed articles published after 2008 were selected except extracts perceived to be of fundamental mileage to the study. However, articles published by staunch international organizations working in the protection of children for years and has produced indefatigable knowledge in commercial sexual exploitation of the children were stealthily appraised. Poverty, which is commonly cited, is not the sole justification for the commercial sexual exploitation of children, even though it contributes to an environment that may sequel to such exploitation. In summation, a range of other complex contributing factors include consumerism, culture, economic disparities, social, political instability, environment, corruption, lack of reporting crimes, lack of and/or inadequate laws, poor enforcement, state lack of interest, debt burden, structural adjustment programmes, the practice of offering women as subservient to men, discriminatory policies, poverty, natural calamities, lack of training, demand and supply, power imbalances, sex trade, families encouragement, philanthropic organizations, internet access, crime and violence, transient workers, freedom of movement, domestic tourists, population expansion, child trafficking, individual, loss of communal farmlands; and porous borders. In conclusion, the causes of child sex tourism can be simply pooled and catalogued into
\end{abstract}

Revised Manuscript Received on January 2, 2020.

* Correspondence Author

Yahya Muhammed Bah1*, Department of Sociology, Faculty of Social and Political Sciences, University of Airlangga, Surabaya, Indonesia: yahyamuhammed@yahoo.co.uk

Pinky Saptandari: Department of Sociology, Faculty of Social and Political Sciences, University of Airlangga, Surabaya, Indonesia social, economic, political, natural, technological, individual; and legal causes

Keywords: child, child sex tourism, perpetrators, survivors, tourist, tourism

\section{INTRODUCTION}

Numerous African societies are split on who or what to blame for the commercial sexual exploitation of children with males often harped on changing traditions, westernization and failure of modern institutions to address moral issues and indecent behaviors the way their forefathers did. Traditional leaders blamed women or mothers who they accused of colluding with their daughters and encouraging them to have boyfriends. They also faulted weak men who are supposed to be heads of households but instead allowed their homes to be controlled by their wives. Women leaders on their parts blamed men for financial irresponsibility and lack of sexual control. Other mothers insist that some daughters are plain stubborn and will not listen to what elders say. Some complained that children's idea or perception about western values and lifestyles as well as increasing clamor over children's rights were making it difficult for them to have control over their children. In all fairness, male elders blamed men for failing to control their carnal urges and transgressing religious and customary laws.

Johansson, L. (2017), findings indicate there are numerous factors responsibility for the continuous persistence of child sex tourism including the culture, economy, social, political, environment, corruption, debt burden, structural adjustment programmes, the practice of offering women as subservient to men, rampant poverty, unlimited natural calamities. McCrann, D. (2017), child sex tourism like all other social problems transcend all layers being economic, social cultural, religious and racial.

\section{AIMS AND METHODOLOGY}

\section{A. Aims}

The fundamental rationale for the literature review is to examine the present scale and degree of the causes of child sex tourism, share knowledge to spark and inspire a process that will usher rapid growth from all directions in the fight against the menace.

\section{B. Methodology}

A systematic review of the literatures using information collected from different sources was actuated. Google Search Engine was used to search these articles. During the search numerous combinations of words and phrases were used to ensure articles reflect the most 
recent knowledge and scholarly works. The systematic searches beget varied and voluminous articles which had to be sieved not only to meet the inclusion and exclusion criteria but to ensure the fundamental objectives of the study are wrangled.

Therefore, only peer-reviewed scholarly publications published after 2008 were selected except extracts perceived to be of fundamental mileage to the study. However, articles published by staunch international organizations known to have been working in the protection of children for years and has produced indefatigable knowledge in commercial sexual exploitation of the children were stealthily appraised.

\section{Inclusion and Exclusion Procedures}

The underneath procedures were followed in articles inclusion. That is, only:

1. Peer-reviewed scholarly articles.

2. Peer-reviewed scholarly articles on child sex tourism.

3. Peer-reviewed scholarly articles published from 2008 to 2019.

4. Articles on international or regional perspectives on child sex tourism.

5. Articles on child sex tourism published by internationals organizations with years of meritorious experiences in child protection.

To exclude some articles from the review, the below captioned criteria were applied. That is:

1. Non-peer reviewed articles.

2. Articles published before 2008 unless critical and impactful.

3. Media generated articles including newspapers.

In spite of the fact that both qualitative and quantitative articles were trawled, majority of the literatures reviewed were 17 (seventeen) which is largely due to a dearth of data. In essence, only peer-reviewed articles and publications by international organizations considered to be trustworthy because they occasioned standard, ethical and robust studies.

\section{RESULT AND DISCUSSION}

The literature review has divulged a wide range of causes which lead to child sex tourism.

\section{A. Social Causes of Child Sex Tourism}

All of us are circumambient by different social environments which together influence who we are. These social institutions include the microsystem (i.e. the family, school, neighborhood, etc.), mesosystem (i.e. interactions between the microsystems themselves), ecosystem (i.e. those social institutions that we are not directly interacting with but do affect us because they affect someone critical in our life e.g. the interactions between parents and their workplaces); and the macro system the outermost layer which encompasses the laws, policies, cultural values, rules, customs, etc. Therefore, it is obvious that our social environment does not only wobble our physical, social, cognitive and psychological development but equally our social behaviors and expectations as it significantly influences what is to be regarded acceptable and unacceptable. In a society where there is ferocious competition for limited resources the moral barometer is not only subjected to oscillation but putrefaction endangering other people's lives especially the vulnerable group. Thus, in spite of the paucity of data some empirical evidences pertinaciously linked child sex tourism with the unswerving moral putrescent at worst genocide. This assertion concurred with the findings of many scholarly publications as captured underneath.

Hawke, A. et al., (2016), half the world population domicile in South Asia where tourism is a principal source of revenue for most nations and communities with the booming of the domestic tourism and the social norms condoning boys engagement in street based-sexual exploitation and girls victimization in brothels and other venues, child sex tourism is on the increase. Similarly, Montgomery, H. (2008), divulged child sex tourism does not happen in the vacuum and as such cannot be abrogated from the cultural and socioeconomic situations of the country but hardly considered and fought against. Hodgson, G. (n.d.) as quoted in Fredette, K. (2009) impacted, child sex tourism though driven by economic gains, consumerism, logging projects destroying forestlands, rural poverty exacerbated by population spike and rapid urbanization are critical factors to reckon with. Furthermore, Zafft, R. et al., (2010) revealed, the causes of child sex tourism are diverse, multifaceted and deeply rooted in socio-economic, cultural, government structures, educational, military occupation, poverty, cultural norms, easy travel, demand and supply, government offering women hostesses to influential visitors, unregulated industries, nations' dependency on the sex industry.

Cotter, K.M. (2009), in a study conducted in the norther province of Thailand unveiled, two-third of the families who sold their daughters preferred to purchase color television and video gadgets though they are capable of keeping their girls in the alternate. McCrann, D. (2017) reported, contextual factors exacerbating the problem of child sexual abuse include patriarchal nature of society, the transactional nature of sexual relations, the low status of children, and the assumption that children are free from HIV virus. McCrann, D. (2017), the patriarchal nature of society has made women and children vulnerable. Johansson, L. (2017) points, the causes of child prostitution are a product of country's history and culture (M'Jid, Najat Maalla, 2014) a former UN Special Rapporteur on the sale of children, child prostitution, and child pornography.

Additionally, Hawke, A. et al., (2016) ${ }^{1}$ vouch safe, though Australia and New Zealand have efficient child protection mechanisms but as an emerging destinations where the awareness of the phenomenon and inadequate laws coexist with strong indigenous norms that fuels the risk, for example, child marriage, forbearance for violence and commercial sex, sexual taboos; and low regards for children, children are increasing becoming vulnerable. Bad social norms for example, male superiority, females being regarded as passive of male sexual desire, victims being regarded as complicit in sexual exploitation, families and communities rejection and ejection of

${ }^{1}$ Hawke, A. et al., (2016) 
homosexuals all contribute to the increase vulnerability of children to sexual exploitation ${ }^{2}$. Chinese erroneous belief that having sex with children can be rejuvenating or can bring good luck to a business travel and the fact that it is the most populous country, the second biggest economy in the world and tourism is on the increase in the country, empirical evidences strongly indicate that child sex tourism will be on the increase if not muzzled ${ }^{3}$. Prodigious growth of unregulated orphanages by foreigners and parents voluntarily giving their children created fertile ground for child sex as most proprietors allowed in all types of visitors as long as they have paid the visiting levy. McCrann, D. (2017), the avoidance of HIV has equally contributed to child sexual abuse as perpetrators believed children are virgin ${ }^{4}$.

Fredette, K. (2009) reports, in addition to the economic and political factors, child sex tourism is caused by deeply rooted cultural beliefs and stereotypes, child sex being approved pegged on male dominance beliefs, false believed that children are less likely to be HIV positive; and the strong conviction that children should support their aging parents by all means. Frederick, J. (2010), in a closely related study divulged, the culture of freedom of movement in South Asian societies often result in boys being prostituted in the streets, beaches, parks, entertainment districts and transits hostelry clubs while girls in establishments like brothels, bars and even Five-Star hotel added Hawke, A. et al., (2016).

\section{B. Economic Causes of Child Sex Tourism}

Studies have emphasized the significance of economic factors that often inveigled people into criminal activities including child sex tourism. With the industry estimated to yield \$2.8billion yearly in USA alone (Bouche, V. et al., 2017), it is axiomatic that there are elephantine economic returns for notorious cartels including perpetrators, intermediaries, clubs, bars, hotels, brothels, managers, families and amoral security and judiciary personnel. With the anomalous level of unemployment, underemployment, widening economic gaps, debt burden, market demand, conspicuous adult sex trade, transient workers, population detonation, farmlands banishment, etc. the economic impulses to engage children in commercial sexual exploitation including child sex tourism is stalwart.

Fredette, K. (2009) $)^{5}$ asserted, the widening economic gaps between developing and developed nations compels impoverished destinations to welcome sex tourists with large disposable income. Similarly, Hawke, A. et al., (2016), numerous nations heavily depend on travel and tourism to bolster their national developments and so too are some households relying on jobs created by the industry thus, escalating the possibilities of not reporting child sex tourism plus the lack of enforcement of legislations meant to regulate the industry. Often, the tourism industry creates opportunities to facilitate the exploitation of children for instance, with disruption of local economies, perpetrators

\footnotetext{
${ }^{2}$ ibib

3 ibib

${ }^{4}$ ibib

${ }^{5}$ Fredette, K. (2009)
}

avail themselves of the tourism infrastructures to reach children ${ }^{6}$.

Russell, S. (2004) as cited in Fredette, K. (2009) laments, because financial gains from illegal trade surpass legitimate wages, impoverished families forced to pay loans with exorbitant interest sometimes; families nimbly succumbed to child sex tourism. In Cotter's (2009), in Thailand it is not unheard of for parents to sell their daughters into sex tourism to resolve family financial crisis for example, to settle debts to continue farming on rice fields to avoid destitution or just to acquire new goods due to modernization for instance, a new television set. McCrann, D. (2017), poverty was the primary explanation for child sexual abuse as victims and families condoned it because they desperately needed financial support for survival.

In addition, Hawke, A. et al., $(2016)^{7}$ unearthed, the presence of adult sex or entertainment trade embolden child sex tourism as the situations present opportunities for situational offenders and child sex recruiters under the disguise of legal businesses like domestic help recruitment agencies. Hawke, A. et al., (2016), Canada and USA are known to be a long time source for perpetrators however; there are evidences that their children are becoming victims at a much younger age due to a combination of factors including sex for survival, increase demand by business travelers attending conferences, transient workers and easy access to internet and other communication technologies by children $^{8}$. In East Asia domestic travelers far outnumber foreign ones and the fact that business travel is increasingly accompanied by the rise of a corporate culture entailing participation in after-hours "meeting" characterizing by alcohol consumption and sex, evidences suggest the domestic tourists should be a cause for concern. Fredette, K. (2009), there is no single cause for child sex tourism but what is certain is it operates on demand and supply principles ${ }^{9}$.

Similarly, Cotter, K.M. (2009) ${ }^{10}$ revealed, though modernization and globalization has resulted in the increase of wealth especially among the elites it has caused impoverishment in the majority due to the dismantling of traditional families, subsistence farming, loss of communal land, shifting from subsistence farming to cash-crop farming and new government policies in favor of mechanized agriculture sending poor farmers away from their lands into slavery. The population expansion has resulted in massive poverty thus, creating a fertile ground for the supply of children whom the traffickers can easily mastermind and exploit ${ }^{11}$.

\section{Political Causes of Child Sex Tourism}

Political stability ever since is a fundamental requirement for inclusive, equitable and sustainable development. With political stability peace and process is assured to all citizenry as communities can reap the benefits of their natural and human endowments. However, when stability aquaplane,

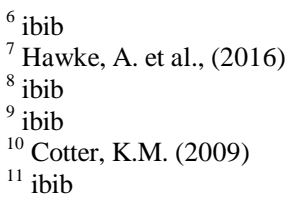


either through accidents or calculated bashes, not only developmental achievements are loss but equally lives and means of survival. When peace and conventional means of survival cannot be assured, desperation rein. With desperation, vulnerability to all menaces is heightened including sex for survival.

Walters, J. et al., (2011) comments, the fundamental causation of child sex tourism in Latin American nations include poverty, political and economic instability, literacy, limited employment opportunities, broken homes, families selling their children, easy access to internet; and bleak financial circumstances for families. Cotter, K.M. (2009), sex tourism thrives in Southeast Asia due to five main factors namely, devastating poverty, armed conflicts, rapid industrialization, an exploding population growth; and radical transition, the brunt of which is bore by impoverished families.

Similarly, OHCHR, (2017 as cited in Johansson, L. (2017) reported, the wellbeing of many children are in catastrophic situations largely due to their national social policies and structures which discriminate against children based on both gender, social and economic status. Fredette, K. (2009) ${ }^{12}$ mapped out, lack of interest in child protection due to inadequate policies and laws, rampant corruption, tolerant of child sex tourism as non-serious offense, granting license to perpetrators to continue victimizing children with impunity and soft hands, patrons acting with no ion of fear of any punishment safe deportation, tantamount to unreserved approval of child sexual abuse. Like some Chinese officials who argued that prostitution is inevitable in any emerging economy, the states that enact policies that indirectly encourage rapid development of prostitution such as the provision of sexual services to foreign military on overseas deployment indirectly sting the growth of the trade despite the anticipated financial returns and support by the World Bank $^{13}$.

Comparably, Hawke, A. et al., (2016) delineated, when crimes are no investigated and perpetrators prosecuted a culture of impunity rein in, paving the way for organized crime and continuous abuse; and under such circumstances victims and families have reasonable grounds not to trust authorities to blazon child abuse.

\section{Legal Causes of Child Sex Tourism}

The progress of any society cannot be severed from effective and efficient justice delivery system. For state to deliver justice, it must promulgate laws and enforce them without fear and favor. Therefore, in the absence of any accountable, independent and corruption immune judiciary, order and moral consciousness becomes scarce commodity paving ways for all genres of social villainies including commercial sexual exploitation of the minors.

Hawke, A. et al., (2016) ${ }^{14}$ adumbrates, over the years, the Western European countries have been the sources of child sex offenders, however, the trend is changing not only

\footnotetext{
${ }^{12}$ Fredette, K. (2009)

13 ibib

${ }^{14}$ Hawke, A. et al., (2016)
}

because they are the number one tourist destination welcoming more than half the global tourists leaving their children vulnerable but also the Central and Eastern European countries which often lack proper legislations to protect children are rapidly emerging as source. Crime and violence often fuel child sex tourism as it results in massive poverty, unemployment, family breakdown, violent gangs; and children running away from homes living in the streets aggravating child sex tourism. Many countries and households rely on income from tourism and travel industry for their survival which has not only increased vulnerability but sparged reporting crimes and the enforcement of child protection critical laws ${ }^{15}$. Fredette, K. (2009), the rate of child sex tourism offenses in comparison to the limited conviction undoubtedly manifest crummy enforcement of legislations. Similarly, under training of security and judiciary officials does not only permit the continuity of the outdated practices in which children are adversarial questioned but treated as culprit resulting in incomplete information gathering, intimidation and lack of cooperation from children which subsequently compromises the whole proceedings however, allowing children to testify via video links can be viable and affordable option.

\section{E. Natural Causes of Child Sex Tourism}

Natural calamities are common phenomena nowadays the aftermath of which can be cataclysmic both to human kind and infrastructural developments. In some instances communities are completely wash off their hard-earned properties and even family members. Under such defoliated or doomed circumstances safety and survival becomes the cardinal priority. In the search for safety and survival some are cajoled into criminal activities and others rendered victims.

Cotter, K.M. (2009) chronicled, disasters and porous borders are also known to have made children more vulnerable for sex trafficking as was the case during 2005 tsunami in which lot of Indonesian children were trafficked despite the government criminalization of it.

\section{F. Technological Causes of Child Sex Tourism}

Today, access to technology is a requisite for inclusive, equitable and sustainable development due to its transformative potentialities. Thus, to transform communities socio-economically and even politically, technology must not only be diverse, progressive but equally available, accessible, affordable; and users-friendly to all. With these fundamental requisites, technology, more especially with the internet, the world is at the fingertips of many people to both create and clutch opportunities and at worse making the commissioning of crime easy, quick and hard to discern rendering several people vulnerable.

Terre des Hommes (2014) as quoted in Hawke, A. et al., (2016) heralded, the proliferation of the internet and associated technologies has exponentially altered the methods of solicitation and exploitation of children by making it easier, faster and

${ }^{15}$ ibib

Published By: 
cheaper for online grooming, cybersex, webcam, etc. resulting in tens of thousands of children in Philippines alone be engaged in webcam child sex tourism in which children perform sexual act in front of a camera controlled by the abuser through a local intermediary. Similarly, Hawke, A. et al., (2016) unearthed, with the unprecedented easy access to mobile technology and expansion in the travel and tourism infrastructures couple with inadequate legislations to punish perpetrator to instill fear plus poor social services to victims, children are becoming most susceptible to child sex tourism in South Asia.

\section{CONCLUSION}

Poverty, which is commonly cited, cannot be the sole justification for the commercial sexual exploitation of children, even though it contributes to an environment that may sequel to such exploitation. In summation, a range of other complex contributing factors include consumerism, culture, economic disparities, social, political instability, environment, corruption, lack of reporting crimes, lack of and/or inadequate laws, poor enforcement, state lack of interest, debt burden, structural adjustment programmes, the practice of offering women as subservient to men, discriminatory policies, poverty, natural calamities, lack of training, demand and supply, power imbalances, sex trade, families encouragement, philanthropic organizations, internet access, crime and violence, transient workers, freedom of movement, domestic tourists, population expansion, child trafficked, loss of communal farmlands; and porous borders exist, which can be simply pooled and catalogued into social, economic, political, natural, technological; and legal causes.

\section{LIMITATIONS}

The fundamental limitations of the study include being conducted within very short period of time, there was no financial support from any institution or individual and above all, the articles reviewed were not without limitations and above all:

- It was not exhaustive review of the literatures on the menace.

- The review was not on all facets of the menace since the causes can be inextricably linked to many other critical strands.

- The cut-off year for the commencement of the reviewed has debarred some expository studies.

- Reviewing articles that are easily accessible disbars hermeneutic and probably more up to date ones.

\section{DECLARATION OF CONFLICT OF INTEREST}

I declare that there is no conflict of interest with respect to the study, authorship and/or publication of the manuscript.

\section{FINANCIAL SUPPORT DECLARATION}

I received no monetary support for the study, authorship and/or publication of this article. This manuscript was solely and wholly financed from my monthly student stipend. I sincerely acknowledge the technical assistance and support of my Gambian colleagues and our Information and Technology Department.

\section{ETHICS APPROVAL}

Ethics approval was not necessary for a systematic literature review study.

\section{REFERENCES}

1. Bouche, V. et al., (2017), (2017): Estimating demand for illicit massage businesses in Houston, Texas, Journal of Human Trafficking, DOI:10.1080/23322705.2017.1374080. Available at: http://dx.doi.org/10.1080/23322705.2017.1374080

http://vanessabouche.com/wp-content/uploads/2017/10/BoucheCrotty2017.pdf

2. Christiansen, L.V. (2015). An Exploratory Case Study on Child Sex Tourism in a Pacific Country: Samoa. Available at: http://researcharchive.vuw.ac.nz/xmlui/bitstream/handle/10063/4409/thesis.pdf ?sequence $=5$

3. Cotter, K.M. (2009). Combating Child Sex Tourism in South East Asia. Available https://onlinelibrary.wiley.com/doi/abs/10.1111/j.1467-6478.2014.00667.x

4. Curley, M. (2014). Combating Child Sex Tourism in South-East Asia: Law Enforcement Cooperation and Civil Society Partnership. Available at: https://onlinelibrary.wiley.com/doi/abs/10.1111/j.1467-6478.2014.00667.x

5. Fredette, K. (2009). International Legislative Efforts to Combat Child Sex Tourism. Available at: https://lawdigitalcommons.bc.edu/cgi/viewcontent.cgi?article=1019\&context=iclr

6. George, B. et al., (2011). Child Sex Tourism: Facilitating Conditions, Legal Remedies and Other Interventions. Available at: https://www.researchgate.net/publication/233158045_Child_sex_tourism_Faci litating_conditions_legal_remedies_and_other_interventions

7. Hawke, A. et al., (2016). Global Study on Sexual Exploitation of Children in Travel and Tourism. Available at: http://cf.cdn.unwto.org/sites/all/files/docpdf/global-report-offenders-move-final. pdf

8. Johansson, L. (2017). Child Prostitution in South East Asia. Available at: https://www.diva-portal.org/smash/get/diva2:1177268/FULLTEXT01.pdf

9. Koops, T. et al., (2017). Child sex tourism - prevalence of and risk factors for its use in a German community sample. Available at: https://bmcpublichealth.biomedcentral.com/articles/10.1186/s12889-017-4270-3

10. McCrann, D. (2017). An Exploratory Study Of Child Sexual Abuse In Tanzania. Available at: https://arrow.dit.ie/cgi/viewcontent.cgi?article=1080\&context=appadoc

11. Montgomery, H. (2008). Buying Innocence: Child Sex Tourists in Thailand. Available https://www.tandfonline.com/doi/abs/10.1080/01436590802106023

12. Panko, T.R. et al., (2012). Child Sex Tourism: Exploring the Issues. Available at:

https://www.researchgate.net/publication/254243493_Child_sex_tourism_Exp loring_the_issues

13. Rao, N. (1999). Sex Tourism in South Asia. Available at: https://www.emerald.com/insight/content/doi/10.1108/09596119910250940/f ull/html

14. Spurrier, K. et al., (2017). Adult Survivors' Recollections and Accounts of Their Involvement in Child Sex Tourism By Way Of Child Prostitution. Available at: http://www.scielo.org.za/pdf/sw/v53n3/08.pdf

http://www.scielo.org.za/scielo.php?script=sci_arttext\&pid=S0037-805420170 00300008

15. Vrancken, P. et al., (2009). International Child Sex Tourism: A South African Perspective. Available at: http://www.corteidh.or.cr/tablas/R21993.pdf

16. Walters, J. et al., (2011). Human Trafficking, Sex Tourism And Child Exploitation On The Southern Border. Available at: http://digitalcommons.library.tmc.edu/cgi/viewcontent.cgi?article=1031\&conte $\mathrm{xt}=$ childrenatrisk

17. Zafft, R. et al., (2010). A Survey of Child Sex Tourism in the Philippines. Available https://digitalcommons.unl.edu/cgi/viewcontent.cgi?article=1021\&context=hu mtrafconf2 


\section{AUTHORS PROFILE}

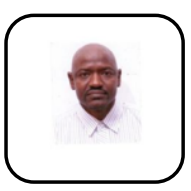

Yahya Muhammed Bah is a full-time Sociology and Social work lecturer at the University of The Gambia (UTG). On part-time, he lectures Sociology and Labor law at the American International University (AIU), Real Estate studies at the Gambia Technical Training Institute (GTTI) and Tourism for-All at the Gambia Tourism and Hospitality Institute (GTHI). He is the founder and Executive Director of Tourism for-All Institute of Psychosocial Work and Community Development, the training arm of Tourism for-All The Gambia Charter. He offers consultancy services to different institutions including the United Nations system in The Gambia. He holds LLB and Masters of Science both in International Social Work and Real Estates Economics.

He has published many articles both in the local and international peer review journals which includes but not limited to: Child Labor in The Gambia: Global Journal of Human-Social Science: Sociology \& Culture, volume 16 Issue 3 Version 1.0 Year 2016. Publisher: Global Journals Inc. (USA); Economic Incentives of Non-handicapping Built Environment (Case study: Tourist sites in Stockholm): International Academic Journal of Business Management. Vol. 3, No. 6, 2016, pp. 72-98. ISSN 2454-2768; Teenage Pregnancy: Teenage Mothers' Experiences and Perspectives: A Qualitative Study: Journal of Health, Medicine and Nursing ISSN 2422-8419: An International Peer-reviewed Journal Vol.29, 2016; Disability and Integration: Gambia Experience: Global Journal of Science Frontier Research: 1 Interdisciplinary, Online ISSN: 2249-4626; HIV/AIDS Risk for Young Female Petty Traders at Car Parks: Journal of HIV for Clinical and Scientific Research; Drugs Abuse Among Street Children: (Case Study: Commercial Vans Casual Apprentices at Car Parks): International Journal of Research in Medical and Basic Sciences; and Divorce and Its Negative Impacts on Children: IJO: International Journal Organization (Social Science \& Humanities Research) Volume 02/Issue 07/July 2019.

$\mathrm{He}$ is a member of many professional bodies including The Gambia Country Coordinating Mechanism (CCM) of the Global Fund to fight Aids, Tuberculosis and Malaria; St Clement University Council; Social Work Certificate National Academic Board of The Gambia; Institute for the Advancement of Children's Right National Board; Gambia of Association of Social Workers; Stockholm Association of Real Estate professionals; National AIDS Council of The Gambia; Community Based Rehabilitation (CBR) Africa Network (CAN); Global Alliance on Accessible Technologies and Environments (GAATES); Global Journal: Certificate of Fellow Membership; and Global Governance Foundation (GGF) Cultural Ambassador. 